\title{
Effects of Blackboard's Discussion Boards, Blogs and Wikis on Effective Integration and Development of Literacy Skills in EFL Students
}

\author{
Majed Alharbi ${ }^{1}$ \\ ${ }^{1}$ College of Languages \& Translation, King Saud University, Riyadh, Saudi Arabia \\ Correspondence: Majed Alharbi, College of Languages \& Translation, King Saud University, Riyadh, Saudi \\ Arabia. E-mail: Linguistics123@hotmail.com
}

Received: February 4, 2015 Accepted: March 20, 2015 Online Published: May 28, 2015

doi:10.5539/elt.v8n6p111 URL: http://dx.doi.org/10.5539/elt.v8n6p111

\begin{abstract}
This study aimed to investigate the effects of the online course tools, specifically discussion boards, blogs and wikis, the built-in facilities of Blackboard as computer-mediated communication integrated in e-learning environments on improving integrated reading and writing and on the attitudes of EFL college students towards literacy skills in e-learning environments. A pedagogical model was designed and described in a background of relevant research. The study made use of both quantitative and qualitative data to investigate the effects of these tools on both reading/writing performance and on attitudes. The findings indicated that the students' performance on an integrated reading/writing test was improved and so were their attitudes towards literacy skills. The findings also showed that the e-course tools at issue facilitated students' interactions and supported learning of the reading/writing skills in a growing online discourse community. The paper ends with a conclusion and discussion of pedagogical implications and recommendations for prospective research.
\end{abstract}

Keywords: integrated reading/writing, literacy skills, CMC, e-learning environment, discussion board, blog, wiki

\section{Introduction}

There has been a pedagogical tradition in Saudi Arabia as in several other countries, spanning decades of literacy instruction in EFL settings that has kept reading and writing in a state of separation (AlOmrani, 2014; Aldosari, 2011; Grabe, 2003; Hirvela, 2001, 2004; Shanahan, 1997; Shanahan \& Lomax, 1988; Shanahan \& Tierney, 1990). However, current research trendshave consistently demonstrated that reading and writing skills should be presented and learnt in tandem (Carson \& Leki, 1993; Ferris \& Hedgecock, 1998; Hirvela, 2001, 2004; Johns, 1993; Lee, 2000; Silva, 1993). This integration can engender 'a symbiosis where EFL learners can learn to write by reading and learn to read by writing' (McArthur, 2014, p. 1).

Although research has made it clear that reading/writing integration is beneficial to literacy development in both EFL and ESOL programs, these "calls for integration are touted in the curriculum only to be ignored in practice" (McArthur, 2014, p. 1).

Nevertheless, current research in second language (L2) and foreign language (FL) has recognized theinterdependence of reading and writing in developing understanding, throwing further doubt on the separation of reading and writing instruction in FL classrooms (Grabe, 2003; Hirvela, 2004; Nelson, 1993).

At present, EFL college reading and/or writing classes tend to present both skills in an integrated fashion. Thistypically occurs through the presentation of writing assignments that involve reading before writing and reading to write tasks. The point of the EFL writing class is that reading thus presented can serve as an essential part of the writing assignment andcanessentiallybe assimilated into the composing process. Thus, integration becomes a key component of the writing classroom, and accumulated literature on reading/writing instruction argues for a paradigm shift toward a reading-writing integration in composition classes (Mekheimer \& Aldosari, 2013; Carson \& Leki, 1993; Grabe, 2003; Hirvela, 2001, 2004).

A pedagogical implication of this research on the reading-writing connection is that bothskills should be taught together and that the integration of reading and writingwould be highly beneficial for enhancing holistic foreign 
language learning (Grabe, 2002; Mekheimer, 2011; Prowse, 2003). Regardless of this research-based implication that reading-writing teaching should beintegrated, there has been little empirical research conducted in traditional FL learning contexts to support this claim, orin e-learning settings.

With recent developments in information and communication technology, interactive multimedia dynamics and e-learning platforms such as Blackboard, integration of reading and writing has become an efficient mechanism for assisting EFL learners to develop their literacy skills. This integration can be done in more communicative and interactive real-life ways as well as to assisting them to overcome reading/writing problems (Álvarez, 2012).

Leu (2000) claimed that the deixis of information and communication technology is progressing rapidly, which means that e-learning requires teachers to adapt to the new meanings of literacy (Leu et al., 2004). This concept of new literacies supports the conventional view of teaching reading and writing skills by integration to meet the demands of today's digital learners. Restricting approaches to reading and writing to print-based material would inhibit language learners in becoming fully literate in the world of today (Arellano-Osuna et al., 2009).

Computer-mediated communication (CMC) environments such as discussion boards, blogs, journals, or wikis are now commonly available with learning management systems (LMs) such as Blackboard. These CMC modes have recently become an integral part of the life style of today's people who communicate through these media on their mobiles or tablets anywhereand anytime.

E-learning platforms, such as Blackboard, are characteristically equipped with facilities that integrate reading and writing in the foreign language, such as discussion boards, blogs and wikis. These facilities are particularly beneficial for language learners to develop their reading and writing skills. They operate in ways that can help both teachers and students discover how the latter's ideas grow and improve over shorter or longer periods of time (Mak \& Coniam, 2008; Lee, 2004; Coyle, 2010; Cabiness, Irvine, \& Grove, 2013; Pena-Shaff, Altman, \& Stephenson, 2005; Smith, 2006; Lloyd-Williams, 2007; Hayes, 1996; Halic, Lee, Paulus, \& Spence, 2010; Maag, 2006; Beach et al., 2008; Lundin, 2008). These tools also provide students with both reflective and interactive feedback and continually involve them in collaborative activities with their peers and teachers in a way that extends the learning opportunities beyond formal instruction times (Álvarez, 2012; Deng \& Yuen, 2011).

Research on the educational benefits of online course tools has demonstrated the benefits of these tools. However, it has investigatedthese tools individually rather than in combination. Therefore, it is important to explore the advantages and limitations of these interactive e-learning platforms in combination for the purpose of integrating reading and writing skillsin the most effective way.For EFL college students, both reading and writing are fundamental communicative skills necessary for academic achievement. Foreign language instruction harnessing e-learning interactive tools is still deeply grounded in textual logic that builds on the conventional culture of the printed page even though education takes place in an e-learning environment (Álvarez, 2012; Sosa, 2009; Laurillard, 2010).

\section{Definition of Terminology}

Integrated language teaching is a relatively new method, grounded in communicative language teaching, content-based and task-based language teaching theories. The integrated-skill approach ... "Exposes English language learners to authentic language and challenges them to interact naturally in the language. Learners rapidly gain a true picture of the richness and complexity of the English language as employed for communication" (Oxford, 2001, p. 5).

A Discussion Board also known as discussion or online forum is synonymous with the traditional online bulletin board where students are prompted to discuss themes related to the course or to voice their opinions on discussion threads created by the course tutor or peers. It provides space for students to publish their opinions based on their guided reading tasks and/or research activities, respond thoughtfully to discussion threads created by the instructor, provide links and resources related to the discussion topic at issue, andconsideratelyrefute another participant's comments (Raleigh, 2015; University of Oregon, 2015).

A blog is one of the Web 2.0 applications that display serial entries, asynchronously developed, by employing simple user interfaces and allowing users to easily maintain content or add new dated entries, with the advantages of inserting graphics, multimedia, video and audio, and text, which is an important aspect of blogging (Deng \& Yuen, 2011).

A wiki is an online course tool used to help language learners and teachers to create and edit web pages in order toencourage collaborative content creation and editing and endow them with a feeling of responsibility, ownership and authority in wiki writing (Goodwin-Jones, 2003; Tonkin, 2005). 


\section{Purpose of the Study}

Previous studies have shown that teaching reading and writing by integration could have positive effects on the development of both skills. Nevertheless, few studies were conducted to tap into the effects of e-learning environments on the development of integrated reading and writing instruction.

The aim of this study was to explore the educational usefulness of educational blogs, discussion boards and wikis as reflective (off-line or asynchronous) and interactive (online or synchronous) e-course tools in an attempt to attain an integral semiotic analysis of the e-learning environment of Blackboard for integrated reading/writing instruction at the college level.

\section{Research Question}

The present study was carried out to answer the following research questions:

1) Is there a positive effect of using the e-course tools of discussion boards, blogs and wikis on developing integrated reading/writing skills in college EFL students?

2) Does integrated reading/writing instruction utilizing the e-course tools of discussion boards, blogs and wikis result in enhancing the learners' attitudes towards reading and writing?

The questions were answered by examining pre-test and post-test scores for two randomly assigned groups of 30 male EFL college students during a 16 week course of studies at King Khalid University. The experimental group was exposed to a blended course using Blackboard as the Learning Management system for e-learning using basic discussion board, blogging and wiki construction guidelines. The control group studied the same material using conventional classroom instruction techniques.

\section{Hypotheses}

The experiment underlying this study was designed to test the following hypotheses (at a significance level of $p$ $\leq 0.01$ ):

1) There are no statistically significant differences between participants' mean scores on the integrated writing and writing test on pretesting for both the experimental and control participants.

2) There are statistically significant differences between the mean post-test scores of the experimental students' writing skills and the mean scores of the control students in favor of the experimental student group.

3) There are statistically significant differences between the experimental and the control participants in their gain scores on writing skills in favor of the experimental group students.

4) There are statistically significant differences between the experimental and the control students in their gain scores on reading skills in favor of the experimental group.

5) There are statistically significant differences between the attitudes of the experimental and the control students toward integrated reading/writing in CMC-based environments on post-testing in favor of the experimental group.

\section{Significance of the Study}

This study investigates whether using the Blackboard tools of discussion boards, blogs and wikis for teaching integrated reading and writing develops EFL college students' literacy skills. Literacy skills are highly significant for the future of these students and for many others pursuing EFL studies they pursue graduate studies as well as for their future careers, particularly including careers as teachers or translators. Findings of the study will help draw out some pedagogical implications for the improvement of using the Blackboard e-learning platform.

\section{Literature Review}

There has been a growing body of literature that has addressed integrated reading and writing instruction in both second language and foreign language research contexts, spanning a period of more than four decades (Allred, 1994; Chamot, Barnhardt, El-Dinary, \& Robins, 1999; Flower \& Hayes, 1994; McMullen, 2009; Moffett, 1983; Oxford, 2001; Scarcella \& Oxford, 1992; Tsung-Yuan \& Oxford, 2002).

Most of this research has provided favorable evidence in support of integrated reading/writing instruction in whole language learning (Almansour \& Alshorman, 2014; AlOmrani, 2014; Oxford, 2001; Scarcella \& Oxford, 1992; Saleem, 2010). Oxford (2001) adeptly explained that this "integrated-skill approach, as contrasted with the purely segregated approach, exposes English language learners to authentic language and challenges them to interact naturally in the language" (p. 5). 
The integrated approach to reading and writing instruction is useful for the cognitive aspects of learning, but it can also be useful for the affective aspects of learning such as motivation and attitudes (Brown, 2001; Celce-Murcia, 2001; Pennycook, 1989; Richard-Amato, 2003).

Evidence supporting the integrated approach, or whole language teaching, followed earlier first/second language research. This research showed that there is a sequence of skill acquisition (Cayer \& Sacks, 1979; Loban, 1963; Strickland, 1964; Strang, 1972):

Listening precedes speaking and reading. Children acquire their native tongue through listening to and imitating the speech of their parents. Speaking is basic to both reading and writing (p. 291).

Growing research since then showed that the integrated approach to the teaching of language skills could lead to noticeable improvements in the overall proficiency of the target language (Al-Ghamari, 2004; Bose, 2003; Faydi, 2003; Mekheimer \& Aldosari, 2013).

The integration approach to teaching reading and writing makes use of either a task-based model of instruction or a content-based pedagogical paradigm, or a hybrid of task-based or content-based language teaching (Oxford, 2001).

In practice, EFL educators favored the application of an integrated reading/writing approach to help EFL learners to use the language for real life, communicative purposes, not only language forms (Flora, 1995; King, 1996; O'Day, 2002). This suggests a need to carry out reading tasks before starting to engage in writing tasks. In fact, research findings support the notion that using reading assignments and media, such as Webquests, reading journals, wikis, and blogs, can foster the integration of reading and writing development in real life communicative situations (Sehlaoui, 2001). Some researchers demonstrated that EFL learners use reading tasks to activate their schemata in a meaningful process which helps them use their reading skills to develop their writing skills (Atwell, 1987; Bartholomae \& Petrosky, 1986; Flower \& Hayes, 1994; Moffett, 1983; Rosenblatt, 1994). Language is viewed as a medium of thinking, feeling, and communicating and reading helps learners to develop their self-awareness, their declarative knowledge and their linguistic knowledge. It helps them not only to learn but also to interact with others. This outcome is expressed by Breen \& Candlin (2001) who explained that ...

"The skills are the meeting point between underlying communicative competence and observable communicative performance; they are the means through which knowledge and abilities are translated into performance, and vice versa" (p. 12).

While recognizing the importance of integrated reading and writing for the acquisition of these skills and for overall language learning, very few studies have sought to investigate the effects of computer-mediated technology, such as Blackboard in helping EFL college learners to develop their literacy skills (Fageeh \& Mekheimer, 2013; Lea \& Street, 2006; Lillis, 2003; McMullen, 2009).

Few studies have investigated the use of the facilities of online learning management platforms, such as Blackboard, in assisting EFL learners to use the language effectively in the use of synchronous chats or asynchronous discussion boards, blogs and wikis (Bacabac, 2008; Cheng, 2007; Goodfellow, 2005).

The structures that EFL college learners receive from their teachers and peers in the construction of discussion threads, blogs and wikis can enable them to learn the disciplinary knowledge in their reading/writing courses as well as to develop these literacy skills for broader communications. The social interaction in creating an online community within the e-learning environment highlights the significant role of socio-communicative interaction among learners "to learn language, learn about language, and learn through language" (Warschauer, 1997, p. 471 , italics are mine to emphasize the intended meanings).

Some studies have explored the use of discussion boards (Bacabac, 2008; Fageeh \& Mekheimer, 2013), blogs (Kuteeva, 2010; Huffaker, 2005; Montero-Fleta \& Pérez-Sabater, 2010; Richardson, 2006), and wikis (Caverly \& Ward, 2008; Coyle, 2010; Campbell \& Ellingson, 2010; Hadjerrouit, 2012; Higdon \& Topaz, 2009; Imperatore, 2009; McPherson, 2006; Pellet, 2012; Schwartz, Clark, Cossarin, \& Rudolph, 2004; J. West \& M. West, 2009; Wichadee, 2010). However, no single study has investigated the combined effects of using these tools in combination for learning to read and write by integration.

These tools, the management of which takes place in a collaborative fashion, supportscognitive development in the learning of reading and writing skills in the target language. For example, discussion boards help in creating opportunities for learners to freely transfer their ideas, feelings and opinions with their teachers and peers in reading and writing for real life purposes. 
In addition, blogging fosters the development of both reading and writing: for example, Huffaker (2005) observed:

"In the classroom, students can have a personal space to read and write alongside a communal one, where ideas are shared, questions are asked and answered and social cohesion is developed." (p. 94)

Blogging supports real-life communication opportunities where reading and writing may occur in an authentic e-environment within a lively onlinecommunity in which active participants get an interactive audience to read their material (Goodwin-Jones, 2003; Ševelj, 2006).

Research findings on the use of wikis for ELT have indicated their usefulness. (Anderman \& Dawson, 2011; Chao \& Lo, 2009; Chen, 2008; Hadjerrouit, 2010; Lund \& Smørdal, 2006; Mattison, 2003; Mindel \& Verma, 2006; Nielsen, 2000; Nokelainen, 2006). For example, the collaborative learning environment of learning management systems (LMSs) have been designed to establish communication systemssuch as forums, discussion boards, blogs, journals, and wikis - tools that can effectively trigger and consolidate EFL learners' cooperation in an interactive online community. Cabiness, Irvine, \& Grove (2013) highlight this benefit as specifically latent in wikis as follows:

Through the use of wikis, groups of individuals collaborate on various topics by adding text, images, videos, as well as other multimedia elements into one cohesive final product ... The intent of wikis is to foster collaboration in an asynchronous working environment (p.39).

Larusson and Alterman (2009) showed that the use of interactive computer-mediated communication tools, such as discussion boards, blogs and wikis, and built in project-related materials can assist in the development of an elastic structure of online learning guided by the learners' interactions in , collaborative ways.

In this respect, collaborative interaction is viewed within the overall socio-cultural perspective of ESL/EFL learning which Warschauer describes as a 'text-mediational view' (Warschauer, 1997, p. 471). According to Warschauer, this perspective...

"links the concepts of expression, interaction, reflection, problem-solving, critical thinking, and literacy with the various uses of talk, text, inquiry, and collaboration in the classroom. This approach provides a useful framework for understanding collaborative learning in the language classroom as well as for evaluating the potential of online education to assist that process" (Warschauer, 1997, p. 472).

The literature shows that EFL learners find a safer environment for learning by using discussion boards, blogs, journals, wikis, and forums. These facilities offer them lively interaction opportunities with their instructors and colleagues, further their social collaborative skills, and get their opinions voiced and responded to in real life communications. However, this research is scarce, and remains insufficient, especially in EFL college settings.

This study was designed to extend the current research by investigating the effectiveness of discussion boards, blogs and wikis as a whole package in improving integrated literacy skills to explore the effect of these strategies on learners" attitudes toward integrated reading and writing in the online environment.

\section{Methodology}

\subsection{Research Method and Design}

This was an experimental research which made use of a pre-test, post-test, control group design (Gay, Mills, \& Airasian, 2008) with the purpose of measuring the effects of the Blackboard tools of discussion boards, blogs and wikis, in teaching an advanced reading to writecourse.The study also made use of qualitative data obtained from an attitudes scale, discussion board entries, comments, and feedback from the participants. The participants in this study were enrolled in a 16-week Academic Writing-4 course in King Khalid University in Saudi Arabia.

\subsection{Instruments \& Validation}

\subsubsection{The Integrated Reading to Write Test}

The researcher used a performance reading/writing test for determining the baseline pre-test scores of the participants, and for post-tests at the end of the study program to obtain the gain scores for calculating performance differences. T-tests wereused to assess the significance of differences between e students' test performance for the experimental and control group participants.

The Integrated Reading/Writing Test is comprised of two parts. Part I asks the participants to read two passages, then write short answers to comprehension, analysis and synthesis questions. Part II requires students to write an argument essay on a topic related to the passages in Part I. The score of Part I is calculated to assess the reading skills separately while the score of Part II is used to assess the writing skills of the participants. The overall score 
on both parts indicates the overall integrated reading/writing performance. Gain scores, indicative of improvement in the participants' performance from pretest to posttest were computed for each participant by subtracting the pretest score from the posttest score.

\subsubsection{Validation of the Integrated Reading to Write Test}

For determining the internal consistency of the Integrated Reading to Write test, the researcher utilized the Pearson Correlation Coefficient to measure the inter-correlations of the test subsets with the entire test. Table 1 describes the results.

Table 1. Correlation coefficients of each skill with total score

\begin{tabular}{ll}
\hline Tested Skills & Correlations with the total Score \\
\hline Reading & .876 \\
Writing & .861 \\
\hline
\end{tabular}

The table indicates that the test has internal consistency validity, significant at .01 level.

\subsubsection{Reliability of the Integrated Reading to Write Test}

The researcher utilized the Cronbach's alpha for all items to assess the reliability co-efficient of the Integrated Reading to Write Test. The Cronbach's alpha obtained was 0.81 , indicating a high level for reliability of the test.

\subsubsection{The Attitude Scale}

An attitude scale was developed and then distributed to the experimental group to assess the effects of the discussion boards, blogs and wikis on the attitudes of EFL college learners toward the integrated reading/writing course. This Attitudes Scale was made of three parts:

Part A: Interactive e-course tools for literacy development

This part consisted of seven items that asked about the effectiveness e-course tools of discussion boards, blogs and wikis on developing reading/writing skills of the students including formal aspects of writing, sentence and paragraph structure, and learners' use of style, register and appropriate lexicon.

Part B: Attitudes toward the e-course tools for literacy development

Part B consisted of six items that investigated the students' attitudes towards the e-course tools for literacy development in the e-learning environment.

Part C: Positive Aspects about the e-Course Tools

Part $\mathrm{C}$ requested the experimental participants to write down what they thought were the most positive features of discussion boards, blogs and wikis over Blackboard.

\subsection{Participants}

The sample of the study was comprised of 60EFL college students, all males, enrolled in Writing- 4 . The participants were assigned to two equal groups. The experimental group enrolled in Writing-IV as a blended course, using Blackboard as the Learning Management System (LMS) for e-learning in King Khalid University. The control group studied the same course as a conventional classroom course. In the first week of instruction, experimental participants in the study were given an opportunity to learn basic discussion board, blogging and wiki construction guidelines and skills as they were enrolled in the blended course of Writing-IV.

\subsection{Procedures of the Study}

The reading-to-write instructor and the EFL learners enrolled in Writing-IV followed a collaborative and constructivist approach to the development of themes and activities for discussion boards, blogs and wikis based on the objectives of the course and with a focus on essential reading and writing skills.

Step 1, in step 1 the instructor and the learners designed the content of the forums, blogs and wikis modules by choosing interesting tasks, assigning students' roles, finding appropriate resources' links for reading materials and tasks, providing sufficient tutor support in the online environment, and finally incorporating evaluation rubrics for assessing students' writing products.

In step 2, the learning/teaching tasks were carried out based on reading/writing phases and provided clear tasks of writing instruction. There were two major phases of implementing thisCMC-based approach to teaching 
reading and writing.

The first phase dealt with the tasks and activities designed for teaching reading and writing by integration. These included pre-writing (planning the writing process and introducing reading tasks and activities for schema activation), writing (outlining, drafting and redrafting), and post-writing (proofreading, revising and editing, and writing the final version).

The second phase was concerned with inter-team evaluations of the integrated reading/writing sessions, which involved students in a cyclical process of wiki reading and feedback. A summary of the experimental stages of the reading and writing processes is provided below. :

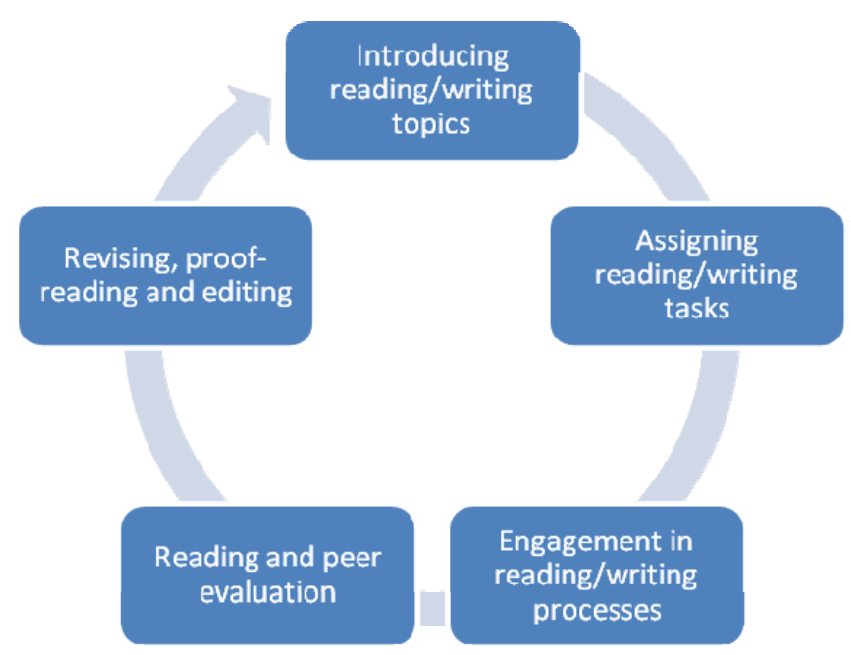

Figure 1. Learning cycle of integrated reading/writing

1) Introducing reading/writing topics:

The online course tutor introduces the reading/writing topics to the students based on the main topics in the course-book. In this phase, learners do a lot of online reading to gain the required background knowledge to build on the themes and discussion threads for their computer-mediated communication.

2) Assigning reading/writing tasks:

The course tutor assigns learners to six cooperative online work teams at the beginning of the course. These teams work together throughout the entire experiment. The tutor during each virtual class assigns to them reading tasks as a pre-writing activity, and then assigns students' roles in a collaborative production process.

3) Engagement in Reading/Writing:

This phase includes three important cyclical steps:

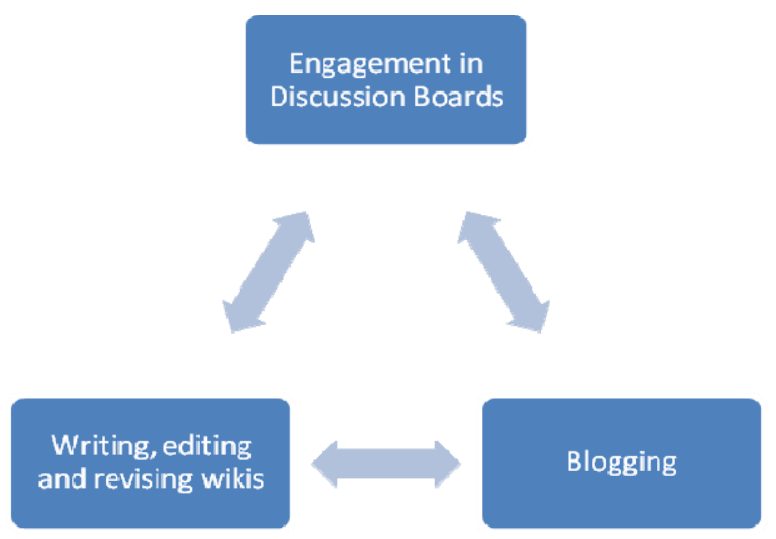

Figure 2. The engagement in integrated reading/writing cycle using discussion boards, blogs and wikis 
After doing the required reading from the tutor-assigned online resources, students are requested to summarize, discuss and respond to discussion threads on the discussion board. Simultaneously, students write their own blogs about their personal experiences in course blogs within Course Tools. They are asked to blog on the difficulties they pass through, the new ideas that occur to them, and on their personal interactions on the discussion board. Based on clues from the tutor, each team starts building their own wiki on the main theme of the course unit.

Each course unit takes three classes/online sessions plus homework per week. The tutor makes sure that each team's wiki should be made public to other teams' members to log in onto the others' wikis to read, provide feedback or edit them if need be. Inter-team work is permitted only on wiki proofreading, editing and revising.

This last step is tutor-monitored. The instructor provides wiki evaluation rubrics to help inter-team members to provide and to access the feedback of students' writings in the wikis. This process of engagement in reading and writing is cyclical and continues with each course unit once a week until the end of the semester.

\section{Results}

\subsection{Quantitative Results from the Reading/Writing Test}

To ensure group equivalence, that is the students initiated the experiment at similar levels of reading/writing skills, a t-test was conducted to assess the significance of differences between the two groups. T-values and their significance levels are shown in Table 2 below.

Table 2. Group equivalence as measured by pretesting of reading and writing skills

\begin{tabular}{lllllll}
\hline Skills & Groups & N & Mean & SD & $t$-value & Sig. \\
\hline \multirow{2}{*}{ Reading Skills } & Experimental & 30 & 36.27 & 4.537 & \multirow{2}{*}{.161} & \multirow{2}{*}{.873} \\
& Control & 30 & 36.32 & 4.922 & & \\
Writing Skills & Experimental & 30 & 35.96 & 4.433 & .061 & .956 \\
\multirow{2}{*}{$\begin{array}{l}\text { Overall Reading \& Writing } \\
\text { Performance }\end{array}$} & Control & 30 & 35.94 & 3.111 & & \\
& Experimental & 30 & 72.23 & 7.762 & \multirow{2}{*}{.057} & .965 \\
& Control & 30 & 72.26 & 6.679 & & \\
\hline
\end{tabular}

The table above shows mean scores on the pre-tests that are almost identical and no statistically significant differences between themon individual reading and writing skills or on the overall integrated reading/writing performance. This finding verifies the first hypothesis and confirms group equivalence before initiating the experiment.

The researcher assessed students' performance on reading/writing after they had completed the Writing IV course with the CMC-based instruction of integrated skills for the experimental group and the traditional teaching of the same course for the control group.

The data presented in Tables 3, 4 and 5 below show a noticeable improvement from pretesting to post-testing on reading/writing skills for the experimental group but a very slight decline for the control group. As the $t$-values indicate, there are statistically significant differences forthe experimentalgroupparticipants $(p=0.01)$ as a result of the CMC instructional model. These findings confirm the second, third and fourth hypotheses.

Table 3. Comparisons of students' performances on the integrated reading/writing post-test

\begin{tabular}{lllllll}
\hline Skills & Groups & $\mathrm{N}$ & Mean & SD & t-value & Sig. \\
\hline \multirow{2}{*}{ Reading skills } & Experimental & 30 & 44.20 & 3.75760 & \multirow{2}{*}{5.373} & .000 \\
& Control & 30 & 35.80 & 4.10607 & & \\
\multirow{2}{*}{ Writing skills } & Experimental & 30 & 43.97 & 2.83431 & \multirow{2}{*}{2.544} & .014 \\
\multirow{2}{*}{ Reading \& writing skills } & Control & 30 & 34.13 & 3.17692 & & \\
& Experimental & 30 & 88.17 & 4.86614 & \multirow{2}{*}{5.246} & .000 \\
& Control & 30 & 69.93 & 6.02316 & & \\
\hline
\end{tabular}


Table 4 shows the differences between pre-test and posttest scores, or gain scores, for the experimental and control groups on these two tests. As noted, there were consistent gains for the experimental group but slight declines for the control group.

Table 4. Gain scores for the experimental and control groups on pre and posttest of reading and writing

\begin{tabular}{lllll}
\hline Skills & Groups & Pretest & Posttest & Gain \\
\hline \multirow{2}{*}{ Reading Skills } & Experimental & 36.27 & 44.20 & 7.93 \\
& Control & 36.32 & 35.80 & -.22 \\
\multirow{2}{*}{ Writing Skills } & Experimental & 35.96 & 43.97 & 8.01 \\
& Control & 35.94 & 34.13 & -1.81 \\
\multirow{2}{*}{ Reading \& Writing Skills } & Experimental & 73.23 & 88.17 & 14.94 \\
& Control & 72.26 & 69.93 & -2.33 \\
\hline
\end{tabular}

Table 5. Pretesting/post-testing t-test comparisons of experimental group performances on the integrated reading/writing test

\begin{tabular}{llllll}
\hline & No & Mean & SD & $t$-value & Sig. \\
\hline Reading skills on pretest & 30 & 36.27 & 4.537 & -7.909 & .000 \\
Reading skills on post-test & 30 & 44.20 & 3.75760 & & \\
Writing skills on pretest & 30 & 35.96 & 4.433 & -4.192 & .000 \\
Writing skills on post-test & 30 & 43.97 & 2.83431 & & \\
Reading \& writing skills on pretest & 30 & 72.23 & 7.762 & -8.715 & .01 \\
Reading \& writing skills on post-test & 30 & 88.17 & 4.86614 & & \\
\hline
\end{tabular}

Data provided in Table 5 showing $t$-test comparisons of the participants' performance for the experimental group on the Integrated Reading/Writing Test demonstrate that the increase in performance for this group was statistically significant $(p<.01$.This further demonstrates that teaching reading and writing in an integrated way by using the facilities of Blackboard's discussion forums, blogs and wikis could yield noticeable improvements in reading/writing together as integrated skills. The lack of any gain for the control group not only suggests significant benefits for an integrated approach but raises significant questions about the effectiveness of conventional teaching methodology.

These findingsarecompatible with the results reported in previous studies, suggesting that an integrated pedagogyfor teaching reading and writing in e-learning environments can be highly effective in improving language skills development (O’Day, 2002; Flora, 1995; King, 1996; Lynch, 1983; Scarcella \& Oxford, 1992; Rosenblatt, 1994; Allred, 1994; Flower \& Hayes, 1994; Oxford, 2001).

\subsection{Quantitative and Qualitative Results from the Attitudes Scale}

An attitudes scale was developed by the researcher to investigate the students' attitudes toward learning integrated reading/writing skills after the participants completed the experiment in the CMC e-learning environment. Responses to statements in a five point scale to indicate degree of agreement indicating Strongly Agree (SA), Agree (A), Uncertain (U), Disagree (D) and Strongly disagree (SD). The attitude scale was only administered to the experimental participants. In order to develop this attitude scale, the researcher reviewed previous research (including Graham, Berninger, \& Fan, 2007; Storch, 2005; Yoon \& Hirvela, 2004). The table below sums up the percentages of responses to Part A on the questionnaire: 
Table 6. Part A: responses of experimental group to interactive e-course tools for literacy development

\begin{tabular}{|c|c|c|c|c|c|}
\hline \multirow[b]{3}{*}{ Statements/Scale of Responses } & \multicolumn{5}{|l|}{ Scale } \\
\hline & & & & & centages \\
\hline & SA & A & $\mathrm{U}$ & $\mathrm{D}$ & SD \\
\hline 1) The online course tools foster interaction with peer readers & $53.67 \%$ & $36.34 \%$ & $0 \%$ & $3.33 \%$ & $6.66 \%$ \\
\hline $\begin{array}{l}\text { 2) The online course tools assist in adapting writing to potential } \\
\text { readers }\end{array}$ & $50 \%$ & $66.7 \%$ & $3.33 \%$ & $3.33 \%$ & $3.33 \%$ \\
\hline $\begin{array}{l}\text { 3) The online course tools help learners use a more formal } \\
\text { variety of English }\end{array}$ & $56.7 \%$ & $33.3 \%$ & $0 \%$ & $3.33 \%$ & $6.66 \%$ \\
\hline $\begin{array}{l}\text { 4) The online course tools help learners adapt academic style, } \\
\text { register, lexicon to the purpose and medium of writing as well } \\
\text { as to the intended audience }\end{array}$ & $55 \%$ & $25.2 \%$ & $3.33 \%$ & $6.66 \%$ & $9.99 \%$ \\
\hline $\begin{array}{l}\text { 5) The online course tools help learners attend to sentence and } \\
\text { paragraph structure }\end{array}$ & $64 \%$ & $36 \%$ & $0 \%$ & $0 \%$ & $0 \%$ \\
\hline $\begin{array}{l}\text { 6) The online course tools help learners check word choice and } \\
\text { word spelling more carefully }\end{array}$ & $48 \%$ & $44.34 \%$ & $3.33 \%$ & $3.33 \%$ & $3 \%$ \\
\hline $\begin{array}{l}\text { 7) The online course tools help learners revise, edit and } \\
\text { proofread material published on blogs and wikis. }\end{array}$ & $56.67 \%$ & $43.33 \%$ & $0 \%$ & $0 \%$ & $0 \%$ \\
\hline
\end{tabular}

These responses indicate that the participantsin the experimental group have an overall positive attitude towards the usefulness of the interactive e-course tools for literacy development. The participants agreed that the online course tools helped them to attend to sentence and paragraph structure equally and helped them to revise, edit, and proofread the material they published on their blogs as well as that on their wikis. They also agreed that these facilities also fostered peer interaction, assisted learners to adapt their writing to their reading audience and helped them to use more formal English in their blogs and wikis. Finally, these tools were seen to have helped them to adapt academic style, register, and lexicon to the purpose and medium of writing as well as to the intended audience.

The facilities of online course tools used in the present study do not have spelling and grammar checkers. However, the postings of the participants demonstrated a minimum of spelling or grammar errors, though the grammaticality of students' posts varied from one participant to another. While they collaboratively worked on their posts or their wikis in order for them to be of acceptable quality, the participants corrected each other's' mistakes as could be tracked by the history function on the Blackboard system. This observation provided additional support for the students' self-reports concerning grammar and spelling.

The peer interactions both within one team and in inter-team interactions could be explained by Lawler's theory of motivation in e-learning environments (Lawler, 1994). According to Lawler (1994), motivation is affected by the expectancy of behavior outcomes. In the case of the participants in the present study, learners are continually on the alert to get comments and feedback from other participants in the case of blogs and wikis. Pena-Shaff, Altman, and Stephenson (2005) also showed that discussion boards also provide learners with impetus to follow and interact with their peers in a positive way that fosters interactive learning.

The findings of the participants' responses to the second part of the attitudes questionnaire indicated that they felt the most positive about the online course tools as is shown in Table 7 and below.

Table 7. Part B: attitudes of experimental group toward elearningintegratedreading/writing via online course tools

\begin{tabular}{lllllll}
\hline & \multicolumn{2}{c}{ Scale } & \multicolumn{3}{c}{ Percentages } \\
\hline $\begin{array}{l}\text { Statements/Scale of Responses } \\
\text { 1) I enjoy using the discussion board, blogs and wikis on }\end{array}$ SA & A2 & U3 & 4 D & 5SD \\
Blackboard
\end{tabular}


2) I feel comfortable with responding to discussion threads, with publishing my blog, and with developing my team's wiki as well as reading and revising other teams' wikis

3) The discussion board, blogs and wikis helped me improve my reading and writing skills

4) I feel my contributions to the discussion board, my blog and the wikis over Blackboard are effective for developing reading $48 \%$ and writing English

\begin{tabular}{|c|c|c|c|c|}
\hline $50.1 \%$ & $39.96 \%$ & $3.33 \%$ & $3.33 \%$ & $3.33 \%$ \\
\hline $53.28 \%$ & $33.48 \%$ & $6.66 \%$ & $0 \%$ & $6.66 \%$ \\
\hline $48 \%$ & $42 \%$ & $2 \%$ & $4 \%$ & $4 \%$ \\
\hline $53.28 \%$ & $33.48 \%$ & $6.66 \%$ & $0 \%$ & $6.66 \%$ \\
\hline $56.67 \%$ & $43.33 \%$ & $0 \%$ & $0 \%$ & $0 \%$ \\
\hline
\end{tabular}

5) I feel my contributions to the discussion board, my blog and the wikis over Blackboard can improve my reading and writing skills by integration

6) The discussion board, the blogs and the wikis can motivate interactive reading and writing

These results indicate that the participants' attitudes toward integrated reading and writing in the e-learning environment using discussion boards, blogs and wikis, f enjoy these e-course tools, and feel comfort with using them. They also appreciated highly their use in improving their reading and writing skills and in a more engaging fashion. These perceptions are consistent with Lee's determinants of the adoption of e-learning systems - namely perceived usefulness, perceived ease of use, and perceived enjoyment (Lee, 2006).

In Part $\mathrm{C}$ of the Attitudes Scale, the experimental participants wrote down what they thought was positive about using the online course tools of discussion boards, blogs and wikis. The responses have been analyzed and categorized in the following:

1) The online course tools fostered my interaction with my peer readers (32\%)

2) The online course tools helped me find out an outlet and an access to my writing (30\%)

3) The online course tools helped me write communicatively in English online (17\%)

4) The online course tools helped to read and write about topics in English in more detail (13\%)

5) The online course tools helped me learn new vocabulary (7\%)

6) The online course tools helped me revise the presentation mode (by proofreading wikis or blogs, editing them, adding new information, deleting or correcting wrong information published in these modes (1\%)

The results above indicate that the informants felt the most positive about interaction with readers $(31 \%)$, then finding an outlet for their writing (29\%), and writing in English on the Internet. The figure below summarizes the results above:

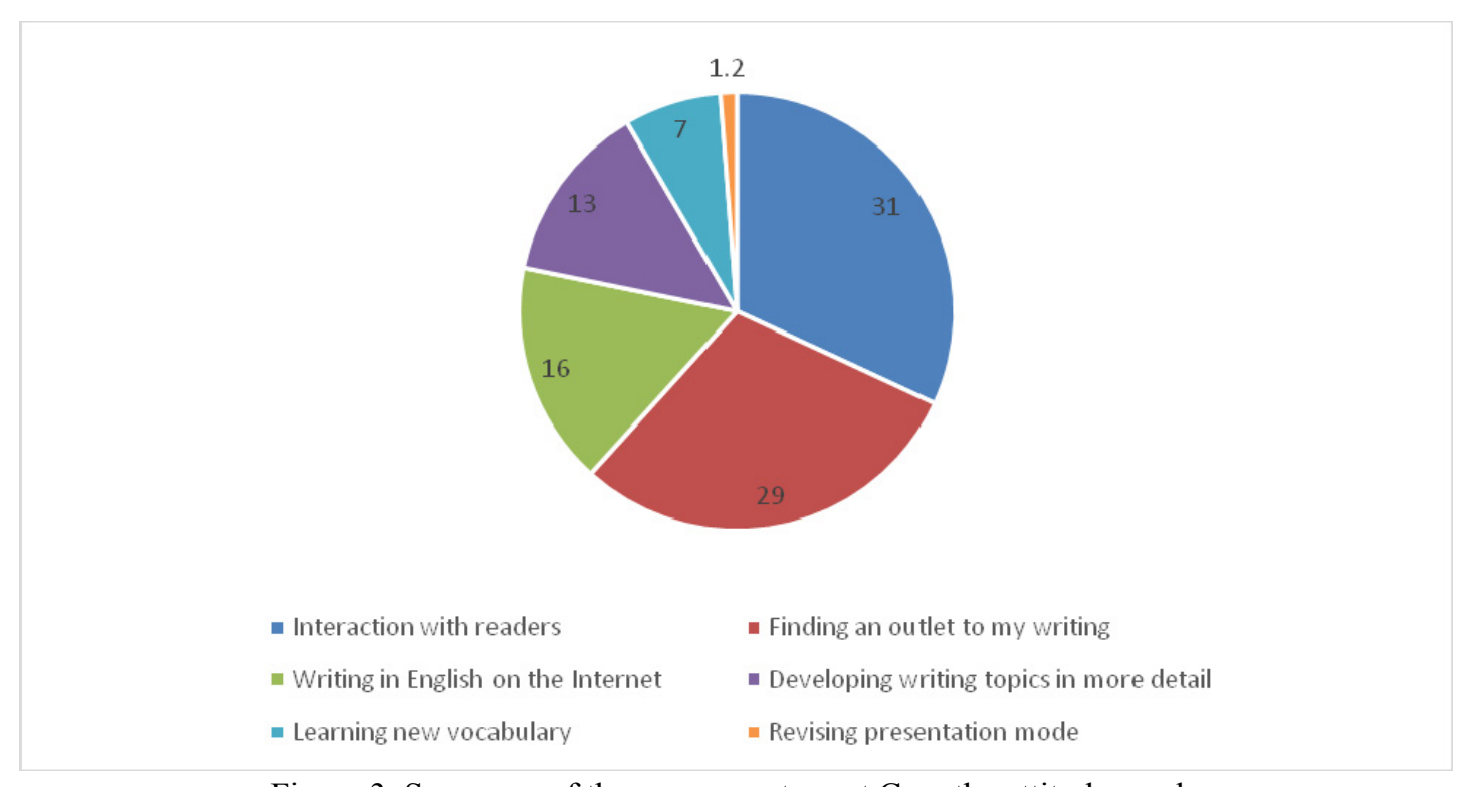

Figure 3. Summary of the responses to part $\mathrm{C}$ on the attitudes scale 
The facilities of Blackboard researched in this study provided real-life communication media where students did their reading and writing for authentic purposes with a genuine and interactive audience. The facilities made it easy for learners to collaborate together in reading and writing as well as in self-evaluation and peer-evaluation, which led to noticeable improvements in integrated reading/writing performance. These findings are congruent with prior research findings, which showed these tools could improve not only reading and writing but also grammar proficiency and written fluency (Goodwin-Jones, 2003; Hewett, 2000; Pelletieri, 2000; Ševelj, 2006). Collaborative learning with these tools was also conducive to increased motivation for, and better attitudes toward learning reading and writing by integration - a finding that resonates with prior research, too (Oravec, 2002; Pinkman, 2005; Zhang, 2009).

\section{Discussion and Conclusion}

The computer-mediated communication tools used in the present study, namely discussion boards, blogs and wikis, available in the e-environment of Blackboard have facilitated collaborative learning and fostered social interaction learning activities geared toward the development of integrated reading and writing skills. The intra-team and inter-team work on discussion boards, blogs and wikis has established an online discourse community that has contributed to the development of students' literacy skills as well as improved their attitudes toward integrated reading/writing. This is consistent with prior research, which showsthat collaborative online discourse communities that actively and interactively use the CMC facilities of e-environments work efficiently toward the acquisition of literacy skills (Goodwin-Jones, 2003; Huffaker, 2005; Ševelj, 2006).

The strategies used in the present study significantly assisted the participants, who were concerned to work toward developing their integrated reading and writing skills in an active, interactive online discourse community. They were motivated to work in this online community, and they learned from one another to a much greater extent than their colleagues in a traditional instructional setting. Participants' postings on discussion boards and in their blogs were interesting to their peers who were interested to read what they had written and work on the advice, feedback and comments posted. This, it was mentioned earlier, could be explained by the expectancy theory of Lawler (1994) and by further research by Pena-Shaff, Altman, and Stephenson (2005) who showed that board threads were motivating and illuminating for learners, especially in reading and writing courses. The socio-affective role of discussion exchanges in the medium of Blackboard reflect the significant role of peer scaffolding and peer-or-tutor mediation, which help learners to better learn how to put into writing what they read.

The present study explored how EFL college learners produced their written texts on the discussion board, in their blogs and in their wikis as a gradually growing process under the influence of CMC facilities built in the e-course tools panel of Blackboard. It provided insights into how the learners read extensively to write, edit, and re-write their wikis by receiving scaffolding from the course tutor and constructive feedback from peers.

In addition, the e-environment of Blackboard made it available for the learners to receive and respond to discussion theme threads that enabled intertextuality, which in turn, facilitated their reading and writing processes where they had access to revisions, edits, additions and improvements on their own and others' writings. This finding supports the investigation by Fageeh and Mekheimer (2013) who concluded that intertextuality provided by the CMC functions of Blackboard helped students to complete their writing tasks and shift from online communication to personalized writing tasks.

The CMC facilities usedhelped induce learners' self-expression and extensive reading in English on the Internet. This further engaged them in reading and writing for real purposes, and for real audiences. The positive findings reported in this study showed that the strategies used improved performance cognitively by developing the integrated reading/writing skills and affectively by developing positive attitudes toward these tools. This is consistent with and supportive of an accumulating body of research that shows how pedagogically effective these tools are for real life communication situations (Beach et al., 2008; Coyle, 2010; Deng \& Yuen, 2011; Hayes, 1996; Lillis, 2003; Montero-Fleta \& Pérez-Sabater, 2010; Pena-Shaff et al., 2005; Smith, 2006, to cite just a few).

The interactive CMC tools of online courses used in this study created a personal space for EFL learners to read and write in their online community. This virtual space enabled them to share their ideas in their social network, and to constructively and positively provide feedback on one another's work, which in turn, helped foster intra-team and inter-team interactions with readers and writers. It also helped in creating an audience and an outlet for their writings. This was a feature of the strategy that the participants liked most as indicated in the responses to the attitude scale. The effects of interactive CMC course tools give learners a sense of ownership of their learning, as well. These findings are also consistent with what has been found in prior research (Kuteeva, 
2010; Huffaker, 2005; Pinkman, 2005; Ševelj, 2006; Yoon \& Hirvela, 2004).

In addition, the CMC tools of forums, blogs, and wikis appeared to help EFL learners to get engaged in real life reading and writing situations where the focus shifts from accuracy to fluency, and from fluency to accuracy in an interactive fashion. Students expressed their ideas and emotions in forums and blogs fluently and asthey developed their wikis, they learned new vocabulary, syntax and gained an academic writing style with more focus on accuracy. This cycle recurs as the communications continue between the participants (Montero-Fleta $\&$ Pérez-Sabater, 2010). Learners focus on content rather than on form while they write in a meaningful and authentic environment to an authentic audience that reads them in specific learning contexts. This finding is commensurate with other findings in relevant literature (Hewett, 2000; Pelletieri, 2000).

These favorable findings support the use ofthe $\mathrm{CMC}$ tools of online courses that incorporate them in genuine learning e-environments where these can be used to help integrate reading and writing activities in authentic learning settings.

It can also be concluded that these tools can best be utilized for self-expression and reflection on students' writings in the virtual space and encourage them to use and produce language for communications. It is also clear that reading better fosters writing development in meaningful communications.

These strategies not only foster the development of integrated reading and writing, but they also improve attitudes toward learning to read and write in English which has important implications for continuing long term benefits

A general conclusion from these findings is that reading and writing teachers should attend to systemic use of these online course tools to help them and their students to integrate reading and writing skills acquisition. Teachers should also consider building a collaborative online discourse community for encouraging peer review in learning cycles comparable to the one described in the present study for developing efficient learning of reading/writing skills and for providing meaningful and useful feedback that fosters both accuracy and fluency in reading and writing.

It is also suggested that prospective research should consider exploring the effects of other online course tools, individually or by integration, such as blogs, journals, forums, google apps, course portfolios, and course messages on the development of literacy skills, listening and speaking, and on motivation for or attitudes toward language learning.

\section{References}

Aldosari, H. (2011). Effects of integrating reading and writing during the reading process on EFL English writing in a Saudi college course: A quasi-experimental study. Paper Presented at the First International Forum on Academic Teaching: Social Inclusion and Information and Communication Technology, $3^{\text {rd }}$ to $5^{\text {th }}$ October 2011, Uberlandia, Minas Gerais, Brazil.

Aldosari, H., \& Mekheimer, M. (2013). The Bandwagon Effect in the Adoption of E-Learning Systems in Language Learning - an Appraisal. GSTF Journal on Computing, 2(4), 61-81.

Aldosari, H., Mekheimer, M., \& Malek, A. (2013). Evaluating an Integrated EFL Teaching Methodology in Saudi Universities: A Longitudinal Study. Funded research with the Grant No Kku-LIN-77-001. Journal of Language Teaching Research, 4(6).

Al-Ghamari, T. (2004). Integrating writing with other skills. Muscat Message, April, 78-81.

Allred, M. (1994). Content-based language instruction and learning a foreign language in high school: The restructuring of a learning environment ( $\mathrm{PhD}$ Dissertation, Utah state University at Logan).

Almansour, N., \& Alshorman, R. (2014). The effect of an extensive program on the writing performance of Saudi EFL university students. International Journal of Linguistics, 6, 247-264.

AlOmrani, H. (2014). Integrating Reading into Writing Instruction in the EFL Programs at Saudi Universities. AWEJ, 5(3), 100-112.

Álvarez, G. (2012). New Technologies in the University Context: The Use of Blogs for Developing Students' Reading and Writing Skills. Universities and Knowledge Society Journal, 9(2), 185-199.

Anderman, E., \& Dawson, H. (2011). Learning with motivation. In R. E. Mayers, \& P. A. Alexander (Eds.), Handbook of Research on Learning and Instruction (pp. 219-214). New York, Routledge.

Arellano-Osuna, A., Braun, C., Manning, M., Leu, D., Raphael, T. E., Reutzel, D. R., ... Lewis, M. M. (2009). New literacies and the 21st century technologies. Retrieved from http://www.reading.org/Libraries/ 
Position_Statements_and_Resolutions/ps1067_NewLiteracies21stCentury.sflb.ashx

Atwell, N. (1987). In the middle: writing, reading, and learning with adolescents. Upper Monclair, NJ: Boynton/Cook.

Bacabac, F. (2008). From cyberspace to print: Re-examining the effects of collaborative online invention on first-year academic writing (Unpublished $\mathrm{PhD}$ ). The Graduate College of Bowling Green State University.

Bartholomae, D., \& Petrosky, A. R. (1986). Facts, artifacts, and Counteracts: Theory and method for a reading and writing course. Portsmouth, NH: Boynton/Cook.

Beach, R., Anson, C., Breuch, L., \& Swiss, T. (2008). Teaching Writing Using Blogs, Wikis, and other Digital Tools. Christopher-Gordon Publishers: Norwood.

Bose, M. (2003). Integrate all the skills while you teach (1). Yemen Times. Retrieved from http://www.yementimes.com/print_article.html

Breen, M. P., \& Candlin, C. N. (2001). The essentials of a communicative curriculum in language teaching. In D. R. Hall, \& A. Hewings (Eds.), Innovation in English language teaching: A reader (pp. 9-26). London: Routledge.

Brown, H. D. (2001). Teaching By Principles: An Interactive Approach to Language Pedagogy (2nd ed.). Longman.

Cabiness, C., Irvine, J., \& Grove, G. (2013). Integrating Wikis in the Support and Practice of Historical Analysis Skills. TechTrends, 57(6), 38-48.

Campbell, K., \& Ellingson, D. A. (2010). Cooperative learning at a distance: An experiment with wikis. American Journal of Business Education, 3(4), 83-89.

Carson, J. G. (2000). Reading and writing for academic purposes. In M. Pally (Ed.), Sustained content teaching in academic ESL/EFL (pp. 19-34). Boston: Houghton Mifflin.

Carson, J. G., \& Leki, I. (1993). Introduction. In J. G. Carson, \& I. Leki (Eds.), Reading in the composition classroom: Second language perspectives (pp. 1-7). Boston, MA: Heinle \& Heinle Publishers.

Caverly, D., \& Ward, A. (2008). Techtalk: Wikis and Collaborative Knowledge Construction. Journal of Developmental Education, 32(2), 36-37.

Cayer, R. R., \& Sacks, R. K. (1979). Oral and written discourse of basic writers: Similarities and differences. Research in the Teaching of English, 11, 121-128.

Celce-Murcia, M. (Ed.). (2001). Teaching English as a Second or Foreign Language (3rd ed.). Heinle \& Heinle.

Chamot, A. U., Barnhardt, S., El-Dinary, P. B., \& Robins, J. (1999). The learning strategies handbook. White Plains, NY: Addison Wesley Longman.

Chao, Y.-C. J., \& Lo, H.-C. (2009). Students' perceptions of wiki-based collaborative writing for learners of English as a foreign language. Interactive Learning Environments, 1-17.

Chen, Y. (2008). The effect of applying wikis in an English as a Foreign Language (EFL) class in Taiwan (Unpublished Doctoral Dissertation). University of central Florida. AAT 3335337.

Cheng, R. (2007). The Role of Computer-mediated Communication in Non-native Speakers' Acquisition of Academic Literacy (Unpublished PhD). University of South Florida.

Coyle, A. C. (2010). Collaborative and Networked Pedagogies: Using Wikis in the Composition Classroom (MA dissertation). University of Wyoming.

Deng, L., \& Yuen, A. (2011). Towards a framework for educational affordances of blogs. Computers \& Education, 56, 441-451.

Fageeh, A., \& Mekheimer, M. (2013). Effects of Blackboard on EFL academic writing and attitudes. JALTCALL Journal, 9(2), 169-196.

Faydi, A. (2003). Integrating language skills \& classroom interaction-The road to effective teaching. Muscat Message, February, 3-9.

Ferris, D., \& Hedgcock, J. (1998). Teaching ESL compositions: Purposes, process, and practice. Mahwah, NJ: Lawrence Erlbaum.

Flora, S. (1995). A case study of literacy development through whole language in a tenth grade language arts 
classroom (Unpublished PhD Dissertation). School of Education, Drake University.

Flower, L., \& Hayes, J. R. (1994). A cognitive process theory of writing. In R. B. Ruddell, M. R. Ruddell, \& H. Singer (Eds.), Theoretical models and processes of reading (pp. 928-950). Newark, DE: International Reading.

Gay, L. R., Mills, G., \& Airasian, P. W. (2008). Educational Research: Competencies for Analysis and Applications: Competencies for Analysis and Applications with My Education Lab. Prentice Hall.

Goodfellow, R. (2005). Academic literacies and e-learning: A critical approach to writing in the online university. International Journal of Educational Research, 43(1), 481-494.

Goodwin-Jones, R. (2003). Blogs and wikis: Environments for on-line collaboration. Language Learning \& Teaching, 7, 12-16.

Grabe, W. (2002). Reading in a second language. In R. B. Kaplan (Ed.), The Oxford handbook of applied linguistics (pp. 49-59). New York: Oxford University Press.

Grabe, W. (2003). Reading and writing relations: Second language perspectives on research and practice. In B. Kroll (Ed.), Exploring the dynamics of second language writing (pp. 243-262), Cambridge: Cambridge University Press.

Graham, S., Berninger, V., \& Fan, W. (2007). The structural relationship between writing attitude and writing achievement in first and third grade students. Contemporary Educational Psychology, 32, 516-536.

Hadjerrouit, S. (2010). A conceptual framework for using and evaluating web-based learning resources in school education. Journal of Information Technology Education, 9, 53-79.

Hadjerrouit, S. (2012). Pedagogical criteria for successful use of wikis as collaborative writing tools in teacher education. In Third International Conference on e-Education, e-Business, e-Management and e-Learning (IC4E 2012), 27, Hong Kong, January 5-7, 11-15.

Halic, O., Lee, D., Paulus, T., \& Spence, M. (2010). To blog or not to blog: Student perceptions of blog effectiveness for learning in a college-level course. Internet and Higher Education. http://dx.doi.org/10.1016/j.iheduc.2010.04.001

Hayes, J. R. (1996). A New Framework for Understanding Cognition and Affect in Writing. In The Science of Writing: Theories, Methods, Individual Differences and Applications, 3-27.

Hazari, S., North, A., \& Moreland, D. (2009). Investigating pedagogical value of wiki technology. Journal of Information Systems Education, 20(2), 187-198.

Hewett, B. (2000). Characteristics of interactive oral and computer-mediated peer group talk and its influence on revision. Computers and Composition, 17(3), 265-288.

Higdon, J., \& Topaz, C. (2009). Blogs and wikis as instructional tools a social software adaptation of just-in-time teaching. College Teaching, 57(2), 105-109.

Hirvela, A. (2001). Incorporating reading into EAP writing courses. In J. Flowerdew, \& M. Peacock (Eds.), Research perspectives on English for academic purposes (pp. 330-346). New York: Cambridge University Press.

Hirvela, A. (2004). Connecting reading and writing in second language writing instruction. Ann Arbor: The University of Michigan Press.

Huffaker, D. (2005). The educated blogger: Using weblogs to promote literacy in the classroom. AACE Journal, 13, 91-98.

Imperatore, C. (2009). Wikis and blogs: Your keys to student collaboration and engagement. Techniques (March), 30-31.

Johns, A. (1993). Reading and writing tasks in English for academic purposes classes: Products, processes, and resources. In J. Carson, \& I. Leki (Eds.), Reading in the composition classroom (pp. 274-289). New York: Newbury House.

King, R. (1996). Implementing a basic college integrated reading/writing course: Lessons in complexity $(\mathrm{PhD}$ Dissertation). School of Education, New York University.

Kuteeva, M. (2010). Wikis and academic writing: Changing the writer-reader relationship. English for Specific Purposes. http://dx.doi.org/10.1016/j.esp.2010.04.007 
Larusson, J., \& Alterman, R. (2009). Wikis to support the 'collaborative' part of collaborative learning. Computer-supported Collaborative Learning, 4, 372-402.

Laurillard, D. (2010). Effective Use of Technology in Teaching and Learning in HE. International Encyclopedia of Education, 4, 419-426.

Lawler, E. E. (1994). Motivation in Work Organizations. San Francisco, California: Jossey-Bass Inc. Publishers.

Lea, M., \& Street, B. (2006). The "Academic Literacies" model: Theory and applications. Studies in Higher Education, 45(4), 368-377.

Lee, D. (2004). Sense of co-accomplishment in collaborative work as threshold in establishing a sense of community in an online course (Doctoral dissertation, University of Texas at Austin).

Lee, I. (2000). Exploring reading-writing connections through a pedagogical focus on 'coherence'. The Canadian Modern Language Review, 57(2), 64-78.

Lee, Y. C. (2006). An empirical investigation into factors influencing the adoption of e-learning system. Online Information Review, 30(5), 517-541.

Leu, D. (2000). Literacy and technology: Diectic consequences for literacy education in an information age. In M. L. Kamil, P. B. Mosenthan, P. D. Pearson, \& R. Barr (Eds.), Handbook of reading research (Vol. 3, pp. 743-770). Mahwah, NJ: Erlbaum.

Leu, D., Kinzer, C. K., Coiro, J., \& Cammack, D. (2004). Toward a theory of new literacies emerging from the internet and other ICT. In R. Ruddell, \& N. Unrau (Eds.), Theoretical models and processes of reading (5th ed.). Newark, DE: International Reading Association.

Lillis, T. (2003). Student writing as academic literacies: drawing on Bulletins to move fromcritique to design. Language and Education, 17(3), 192-207.

Lloyd-Williams, A. (2007). Introduction to Digital Environments for Learning Assignment. Retrieved December 2014, from http://www.education.ed.ac.uk/e-learning/gallery/lloyd_williams_communication.pdf

Loban, W. D. (1963). The language of elementary school children. National Council of Teachers of English Research Report No.1. Campaign, Illinois: National Council of Teachers of English.

Lund, A., \& Smørdal, O. (2006). Is there a space for the teacher in a wiki? Proceedings of WikiSym'06, August, 21-23, 2006, Odense, Denmark, 27-45.

Lundin, R. (2008). Teaching with Wikis: Toward a Networked Pedagogy. Computers and Composition, 25(1), $432-448$.

Lynch, A. (1983). A program to develop the integration of comprehension skills. ELT Journal, 37(1), 58-61.

Maag, M. (2006). Podcasting and MP3 players: Emerging education technologies. CIN: Computers, Informatics, Nursing, 9-13.

Mak, B., \& Coniam, D. (2008). Using wikis to enhance and develop writing skills among secondary school students in Hong Kong. System, 36(2), 437-455.

Mattison, D. (2003). Quickiwiki, Wiki, Twiki, Zwiki and the Plone Wars wiki as a PIM and collaborative content tool. Searcher, 4(11), 32-48.

McArthur, D. (2014). Integrating Reading and Writing for Florida's ESOL Program (Unpublished MA Thesis). University of South Florida. UMI Number: 1553833.

McMullen, M. (2009). Using language learning strategies to improve the writing skills of Saudi EFL students: Will it really work? System, 37, 418-433.

McPherson, K. (2006). Wikis and literacy development. Teacher Librarian, 34(1), 67-70.

Mekheimer, M. (2011). The impact of using videos on whole language learning in EFL context. Arab World English Journal, 2(2), 5-39.

Mindel, J. L., \& Verma, S. (2006). Wikis for teaching and learning. Communications of AIS, 18(1), 2-38.

Moffett, J. (1983). Teaching the universe of discourse. Boston: Houghton Mifflin.

Montero-Fleta, B., \& Pérez-Sabater, C. (2010). A research on blogging as a platform to enhance language skills .Procedia Social and Behavioral Sciences, 2, 773-777.

Nelson, G. (1993). Reading and writing: Integrating cognitive and social dimensions. In J. G. Carson, \& I. Leki 
(Eds.), Reading in the composition classroom: Second language perspectives (pp. 315-330). Boston: Heinle \& Heinle.

Nielsen, J. (2000). Designing Web Usability: The Practice of Simplicity. Indianapolis, New Riders.

Nokelainen, P. (2006). An empirical assessment of pedagogical usability criteria for digital learning material with elementary school students. Educational Technology \& Society, 9(2), 178-197.

O'Day, P. (2002). Reading while listening: increasing access to print through the use of audio books (Unpublished PhD Dissertation). Boston College, Lynch Graduate School of Education.

Oravec, J. (2002). Bookmarking the World: Weblog Applications in Education. Journal of Adolescent and Adult Literacy, 45(7), 616-621.

Oxford, R. (2001). Integrated Skills in the ESL/EFL Classroom. ERIC Digest. ED456670.

Pellet, S. (2012). Wikis for Building Content Knowledge in the Foreign Language Classroom. CALICO Journal, 29(2), 224-248.

Pellettieri, J. (2000). Negotiation in cyberspace: The role of chatting in the development of grammatical competence. In M. Warschauer, \& R. Kern (Eds.), Network-based language teaching: Concepts and practice (pp. 59-86). New York: Cambridge University Press.

Pena-Shaff, J., Altman, W., \& Stephenson, H. (2005). Asynchronous online discussions as a tool for learning: Students' attitudes, expectations, and perceptions. Journal of Interactive Learning Research, 16, 409.

Pennycook, A. (1989). The concept of method, interested knowledge, and the politics of language teaching. TESOL Quarterly, 23(4), 589-615.

Pinkman, K. (2005). Using Blogs in the Foreign Language Classroom: Encouraging Learner Independence. The JALT CALL Journal, 1(1).

Prowse, P. (2003). Extensive reading. English Teaching Professional, 27, 40.

Raleigh, D. (2015). Keys to Facilitating Successful Online Discussions. Retrieved January 17, 2015, from http://www.uwsa.edu/ttt/raleigh.htm

Richard-Amato, P. (2003). Making It Happen: From Interactive to Participatory Language Teaching (3rd ed.). Pearson ESL.

Richardson, W. (2006). Blogs, wikis, podcasts, and other powerful tools for the classrooms. California: Corwin Press, Thousand Oaks.

Rosenblatt, L. M. (1994). The transactional theory of reading and writing. In R. B. Ruddell, M. R. Ruddell, \& H. Singer (Eds.), Theoretical models and processes of reading (pp. 1055-1092). Newark, DE: International Reading Association.

Saleem, B. A. A. (2010). Impact of Extensive Reading on Literacy Perceptions and on EFL Writing Quality of English Major Students at the Islamic University of Gaza (MA Thesis). The Islamic University. Retrieved December 24, 2014, from http://library.iugaza.edu.ps/Thesis/90263.pdf

Scarcella, R., \& Oxford, R. (1992). The tapestry of language learning: The individual in the communicative classroom. Boston: Heinle \& Heinle.

Schwartz, L., Clark, S., Cossarin, M., \& Rudolph, J. (2004). Educational wikis: Features and selection criteria. The International Review of Research in Open and Distance Learning, 5(1).

Ševelj, M. (2006). Weblogs as Dynamic Learning Spaces. Retrieved December 10, 2014, from http://grail.oise.utoronto.ca/blog/karaisko/files/2007/12/weblogs_dynamic_learning_spaces.pdf

Shanahan, T. (1997). Reading-writing relationships, thematic units, inquiry learning: In pursuit of effective integrated literacy instruction. The Reading Teacher, 51(1), 12-19.

Shanahan, T., \& Lomax, R. G. (1988). A developmental comparison of the three theoretical models of the reading-writing relationships. Research in the Teaching of English, 22(2), 196-212.

Shanahan, T., \& Tierney, R. J. (1990). Reading-writing connections: The relations among three perspectives. In Zutzell, \& S. McCormick (Eds.), Literacy theory and research: Analysis from multiple paradigms (pp. 13-34). Chicago: National Reading Conference.

Silva, T. (1993). Toward an understanding of the distinct nature of L2 writing. TESOL Quarterly, 27, 757-767. 
Smith, C. (2006). Synchronous Discussion in Online Courses: A Pedagogical Strategy for Taming the Chat Beast. $\quad$ Retrieved December 2014, from http://www.innovateonline.info/index.php?view=article\&id=246\&action $=$ article

Sosa, T. (2009). Visual literacy: The missing piece of your technology integration course. TechTrends, 53(2), $55-58$.

Storch, N. (2005). Collaborative writing: Product, process, and students' reflections. Journal of Second Language Writing, 14, 153-173.

Strang, R. (1972). Developing oral expression. In H. D. Funk, \& D. Triplett (Eds.), Language Arts in the Elementary School: Readings (pp. 287-293). Philadelphia: J. P. Lippincott Company.

Strickland, R. (1964). The contributions of structural linguistics to the teaching of reading, writing, and grammar in the elementary school. Bulletin of the School of Education, Indiana University, 40.

Tonkin, E. (2005). Making the Case for a Wiki. Ariadne. Retrieved January 1, 2015, from http://www.ariadne.ac.uk/issue42/tonkin/

Tsung-Yuan, H., \& Oxford, R. (2002). Comparing Theories of Language Learning Strategies: A Confirmatory Factor Analysis. The Modern Language Journal, 86(3), 368-383.

University of Oregon. Teaching and Learning Centre. (2015). Generating and Facilitating Engaging and Effective Online Discussions. Retrieved January 17, 2015, from http://tep.uoregon.edu/technology/ blackboard/docs/discussionboard.pdf

Warschauer, M. (1997). Computer-mediated collaborative learning: Theory and practice. The Modern Language Journal, 81, 470-481.

West, J., \& West, M. (2009). Using Wikis for Online Collaboration: The Power of the Read-Write Web. San Francisco: Jossey-Bass.

Wichadee, S. (2010). Using wikis to develop summary writing abilities of students in an EFL class. Journal of College Teaching and Learning, 7(12), 5-10.

Yoon, H., \& Hirvela, A. (2004). ESL student attitudes toward corpus use in L2 writing. Journal of Second Language Writing, 13, 257-283.

Zhang, W. (2009). Blogging for Doing English Digital: Student evaluations. Journal of Computers and Composition, 27(4), 266-283.

\section{Appendix A}

\section{The Integrated Reading/Writing Test}

Directions: Skim the following two passages, each of which presenting two different views on the same issue. After you finish skimming the articles, you will write the answers to eight questions based on the reading passages. In this section you will be graded on content and language: what you say and how you say it. You will have 45 minutes.

Part I:

A: Definition and Benefits of Genetic Engineering. Excerptfroma feature articlepublishedbyWikipedia - the Online Encyclopedia

Genetic engineering, also called genetic modification, is the direct manipulation of an organism's genome using biotechnology.

Humans have altered the genomes of species for thousands of years through selective breeding, or artificial selection as contrasted with natural selection, and more recently through mutagenesis. Genetic engineering as the direct manipulation of DNA by humans outside breeding and mutations has only existed since the 1970s. The term "genetic engineering" was first coined by Jack Williamson in his science fiction novel Dragon's Island, published in 1951, one year before DNA's role in heredity was confirmed by Alfred Hershey and Martha Chase, and two years before James Watson and Francis Crick showed that the DNA molecule has a double-helix structure.

New DNA may be inserted in the host genome by first isolating and copying the genetic material of interest using molecular cloning methods to generate a DNA sequence, or by synthesizing the DNA, and then inserting 
this construct into the host organism. Genes may be removed, or "knocked out", using a nuclease. Gene targeting is a different technique that uses homologous recombination to change an endogenous gene, and can be used to delete a gene, remove exons, add a gene, or introduce point mutations.

An organism that is generated through genetic engineering is considered to be a genetically modified organism (GMO). The first GMOs were bacteria in 1973 and GM mice were generated in 1974. Insulin-producing bacteria were commercialized in 1982 and genetically modified food has been sold since 1994. Goldfish, the first GMO designed as a pet, was first sold in the United States December in 2003.

Genetic engineering techniques have been applied in numerous fields including research, agriculture, industrial biotechnology, and medicine. Enzymes used in laundry detergent and medicines such as insulin and human growth hormone are now manufactured in GM cells, experimental GM cell lines and GM animals such as mice or zebrafish are being used for research purposes, and genetically modified crops have been commercialized.

Genetic engineering alters the genetic make-up of an organism using techniques that remove heritable material or that introduces DNA prepared outside the organism either directly into the host or into a cell that is then fused or hybridized with the host. This involves using recombinant nucleic acid (DNA or RNA) techniques to form new combinations of heritable genetic material followed by the incorporation of that material either indirectly through a vector system or directly through micro-injection, macro-injection and micro-encapsulation techniques.

Genetic engineering does not normally include traditional animal and plant breeding, in vitro fertilization, induction of polyploidy, mutagenesis and cell fusion techniques that do not use recombinant nucleic acids or a genetically modified organism in the process. However the European Commission has also defined genetic engineering broadly as including selective breeding and other means of artificial selection. Cloning and stem cell research, although not considered genetic engineering, are closely related and genetic engineering can be used within them. Synthetic biology is an emerging discipline that takes genetic engineering a step further by introducing artificially synthesized genetic material from raw materials into an organism.

If genetic material from another species is added to the host, the resulting organism is called transgenic. If genetic material from the same species or a species that can naturally breed with the host is used the resulting organism is called cisgenic. Genetic engineering can also be used to remove genetic material from the target organism, creating a gene knockout organism. In Europe genetic modification is synonymous with genetic engineering while within the United States of America it can also refer to conventional breeding methods. The Canadian regulatory system is based on whether a product has novel features regardless of method of origin. In other words, a product is regulated as genetically modified if it carries some trait not previously found in the species whether it was generated using traditional breeding methods (e.g., selective breeding, cell fusion, mutation breeding) or genetic engineering. Within the scientific community, the term genetic engineering is not commonly used; more specific terms such as transgenic are preferred.

\section{B: Controversies against Genetic Engineering.Excerptsfromtwo feature articlespublishedbyWikipedia-the Online Encyclopedia}

Critics have objected to use of genetic engineering per se on several grounds, including ethical concerns, ecological concerns, and economic concerns raised by the fact GM techniques and GM organisms are subject to intellectual property law. GMOs also are involved in controversies over GM food with respect to whether food produced from GM crops is safe, whether it should be labeled, and whether GM crops are needed to address the world's food needs. See the genetically modified food controversies article for discussion of issues about GM crops and GM food. These controversies have led to litigation, international trade disputes, and protests, and to restrictive regulation of commercial products in some countries.

It has been speculated that genetic engineering could be used to change physical appearance, metabolism, and even improve physical capabilities and mental faculties like memory and intelligence, although for now these uses are limited to science fiction. These speculations have in turn led to ethical concerns and claims, including the belief that every fetus has an inherent right to remain genetically unmodified, the belief that parents hold the rights to modify their unborn offspring, and the belief that every child has the right to be born free from preventable diseases. On the other hand, others have made claims that many people try to improve themselves already through diet, exercise, education, cosmetics, and plastic surgery and that accomplishing these goals through genetics could be more efficient and worthwhile. This view sees the prevention of genetic diseases as a duty to humankind in preventing harm to future generations.

Genetic enhancement is considered morally contentious, however, and access to enhancement procedures will 
probably be regulated. Possible regulatory schemes include a complete ban of genetic enhancement, provision of genetic enhancement procedures to everyone, or a system of professional self-regulation.

Perhaps the most practical regulatory approach is the self-regulation of health professionals. The American Medical Association's Council on Ethical and Judicial Affairs has stated that "genetic interventions to enhance traits should be considered permissible only in severely restricted situations: 1) clear and meaningful benefits to the fetus or child; 2) no trade-off with other characteristics or traits; and 3) equal access to the genetic technology, irrespective of income or other socioeconomic characteristics."

Genetically modified foods controversies are disputes over the use of foods and other goods derived from genetically modified crops instead of conventional crops, and other uses of genetic engineering in food production. The dispute involves consumers, farmers, biotechnology companies, governmental regulators, non-governmental organizations, and scientists. The key areas of controversy related to genetically modified food (GMO food) are whether such food should be labeled, the role of government regulators, the objectivity of scientific research and publication, the effect of genetically modified crops on health and the environment, the effect on pesticide resistance, the impact of such crops for farmers, and the role of the crops in feeding the world population.

While there is concern among the public that eating genetically modified food may be harmful, there is broad scientific consensus that food on the market derived from these crops poses no greater risk to human health than conventional food. The safety assessment of genetically engineered food products by regulatory bodies starts with an evaluation of whether or not the food is substantially equivalent to non-genetically engineered counterparts that are already deemed fit for human consumption. No reports of ill effects have been documented in the human population from genetically modified food. Although labeling of genetically modified organism (GMO) products in the marketplace is required in many countries, it is not required in the United States or Canada and no distinction between marketed GMO and non-GMO foods is recognized by the U.S. Food and Drug Administration.

Opponents of genetically modified food, such as the advocacy groups Organic Consumers Association, the Union of Concerned Scientists, and Greenpeace, say risks have not been adequately identified and managed, and they have questioned the objectivity of regulatory authorities. Some groups say there are unanswered questions regarding the potential long-term impact on human health from food derived from GMOs, and propose mandatory labeling or a moratorium on such products. Concerns include contamination of the non-genetically modified food supply, effects of GMOs on the environment and nature, the rigor of the regulatory process, and consolidation of control of the food supply in companies that make and sell GMOs.

Directions: Answer the following questions based on the readings. There are several possible ways to answer each question. You shouldyou're your own words as much as possible; you will not find the answers written word forword in the readings. Your answers will be graded on content and accurate use of English. Be sure to write complete sentences. NOTE: Your answer will be marked down if it contains fewer than 10 words or if your answer consists mainly of words taken directly from the readings.

NOTE: On the actual test there is more room to write responses!

1) What are the main arguments in passage $A$ ?

2) What are some of the most important applications of genetic engineering, according to passage A?

3) According to passage A, How do scientists differentiate between transgenics and cisgenics? How does this affect the applications of genetic engineering to breeding methods?

4) What are the main arguments in passage B?

5) What are some of the most important negative effects of genetic engineering, according to passage $B$ ?

6) What are the effects of geneticallymodifiedfoods which are sometimescalled "Franken foods" on human health according to passage $\mathrm{B}$ ?

7) How do the opinions of the two authors compare with regard to the use of genetic engineering to make plants resistant to viruses or bacteria?

8) How might the author of passage B respond to passage A's prediction that "never again will people know the joy of eating naturally produced, fresh foods"?

Part II: Writing an argumentative essay

Directions: Write a well-organized academic essay on the topic below. Your essay will be graded on content, 
organization, and appropriate use of English. You may refer to the reading passages while you are writing.

ESSAY TOPIC: Some people believe that genetically modified plants are dangerous to our health and to the environment. Others believe that genetic engineering is an important tool in feeding the world's population. Which position do you support? Use specific information from at least one of the two articles to support your ideas.

You may use this space for notes. Write your essay on the lined paper. You will have 45 minutes to write your essay.

\section{Appendix B}

\section{Students' Questionnaire}

This questionnaire is designed to investigate your attitudestowardthe use of CMC e-course tools of Discussion boards, Blogs and Wikis in teaching integrated reading and writing skills. There is no right or wrong answer for each question. Please respond to all sections of the questionnaire.

Part A: Interactive e-course tools for literacy development

Please read each statement and indicate how far you agree or disagree with it.

$\mathrm{SA}=$ strongly agree; $\mathrm{A}=$ agree; $\mathrm{U}=$ uncertain; $\mathrm{D}=$ disagree; $\mathrm{SD}=$ strongly disagree

1) The online course tools foster interaction with peer readers.
SD
$\mathrm{D}$
U
A
SA

2) The online course tools assist in adapting writing to potential readers.
SD
D
U
A
SA

3) The online course tools help learners use a more formal variety of English.
SD
D
U
A
SA

4) The online course tools help learners adapt academic style, register, lexicon to the purpose and medium of writing as well as to the intended audience.
SD
D
U
A
SA

5) The online course tools help learners attend to sentence and paragraph structure.
SD
D
U
A
SA

6) The online course tools help learners check word choice and word spelling more carefully.
SD
D
U
A
SA

7) The online course tools help learners revise, edit and proofread material published on blogs and wikis.
SD
D
$\mathrm{U}$
A
SA

Part B: Attitudes toward learning integrated reading/writing via online course tools

Please read each statement and indicate your degree of agreement or disagreement.

$\mathrm{SA}=$ strongly agree; $\mathrm{A}=$ agree; $\mathrm{U}=$ uncertain; $\mathrm{D}=$ disagree; $\mathrm{SD}=$ strongly disagree

1) I enjoying using the discussion board, blogs and wikis on Blackboard.
SD
D
$\mathrm{U}$
A
SA

2) I feel comfortable with responding to discussion threads, with publishing my blog, and with developing my team's wiki as well as reading and revising other teams' wikis.
$\mathrm{SD}$
$\mathrm{D}$
$\mathrm{U}$
A
SA

3) The discussion board, blogs and wikis helped me improve my reading and writing skills.
SD
$\mathrm{D}$
$\mathrm{U}$
A
SA

4) I feel my contributions to the discussion board, my blog and the wikis over Blackboard are effective for developing reading and writing English.
SD
D
U
A
SA

5) I feel my contributions to the discussion board, my blog and the wikis over Blackboard can improve my reading and writing skills by integration. 
SD D U A A

6) The discussion board, the blogs and the wikis can motivate interactive reading and writing.

SD

$\mathrm{D}$

$\mathrm{U}$

$\mathrm{A}$

SA

Part C: Positive aspects about the e-course tools

Write down what they thought were the most noticed positive features or characteristics of using the facilities of discussion boards, blogs and wikis over Blackboard

\section{Copyrights}

Copyright for this article is retained by the author(s), with first publication rights granted to the journal.

This is an open-access article distributed under the terms and conditions of the Creative Commons Attribution license (http://creativecommons.org/licenses/by/3.0/). 